JIEB (ISSN : 2442-4560) available online at : ejournal.stiepancasetia.ac.id

\title{
ANALISIS IMPLEMENTASI DEMING'S CYCLE DALAM UPAYA MENGATASI MASALAH DISTRIBUSI SEMEN DI PT. INDOCEMENT TUNGGAL PRAKARSA Tbk. PLANT 12 TARJUN KABUPATEN KOTABARU KALIMANTAN SELATAN
}

\author{
Suryana \\ PT. Indocement Tunggal Prakarsa,Tbk Plant 12 Kalimantan Selatan \\ Tarjun, Kecamatan Kelumpang Hilir, Kabupaten Kotabaru, Kalimantan Selatan \\ e-mail : surpipi354@gmail.com
}

\begin{abstract}
The aim of the research was to the got description of implemented Deming's Cycle in the solved of Distribution's problem in order to delivery budgeted from Marketing Division have been realiting for customer satisfaction. Descriptif quantitative methode was used in this research. The result of reaserch that the distribution cement problem like loading failure of bag cement to vessel from system computerization have solved by Deming's Cycle, the begin from Plan by problem identification and than Do by do improvement which effective solution and than Check by comparison between before and after improvemen and than Action like maked the new standardization .
\end{abstract}

Keywords: Analysis, Deming's Cycle, Cement Distribution, PT. Indocement Tunggal Prakrasa Tbk

\begin{abstract}
Abstrak: Tujuan dari penelitian ini adalah untuk mendapatkan gambaran yang jelas mengenai implementasi Deming Cycle dalam mengatasi masalah distribusi semen agar budget pengiriman yang ditetapkan oleh bagian marketing dapat terealisasi sehingga kepuasan pelanggan dapat terpenuhi. Metode yang digunakan adalah dengan menggunakan metode deskriptif kuantitatif. Hasil penelitian diketahui bahwa permasalahan pada distribusi semen dalam bentuk gangguan pemuatan semen bag ke kapal yang berasal dari sistem komputerisasi dapat diatasi dengan menggunakan Deming Cycle mulai dari Plan dengan dengan melakukan identifikasi masalah, dilanjutkan dengan Do dengan melaksanakan perbaikan yang merupakan solusi pemecahan masalah, kemudian dilanjutkan dengan Check berupa penelitan terhadap hasil setelah perbaikan dan membandingkannya dengan kondisi sebelum perbaikan, serta Action yang merupakan tindak lanjut penentapan standar.
\end{abstract}

Kata Kunci: Analisis, Deming Cycle, Distribusi Semen, PT Indocement Tunggal Prakarsa Tbk

\section{Latar Belakang}

Dalam penjabaran Mata Kuliah Manajemen Operasional dijelaskan bahwa Tugas utama manajer yang berkaitan dengan perbaikan atau peningkatan kualitas adalah membuat keputusan yang mampu meningkatkan kinerja sistem kualitas organisasi. Dengan demikian tugas manajer dalam organisasi bisnis global adalah membuat keputusan yang berkaitan dengan masalah - masalah kualitas sehingga

organisasi bisnis diharapkan dapat mencapai tujuannya, seperti meningkatkan produktivitas, memperluas pangsa pasar (market share), meningkatkan keuntungan, mengurangi biaya, dan lain-lain, yang pada prinsipnya akan meningkatkan kinerja bisnis dan industri itu dalam situasi ekonomi yang sangat kompetitif. Menurut Vincent Gaspersz (2005 : 8) bahwa Manajer dalam praktek bisnis global selalu berpikir melalui masalah 
kualitas dan membicarakan masalah kualitas itu berdasarkan data atau fakta.

Salah satu ciri yang menonjol dalam era pasar bebas ( barang dan / atau jasa ) yang ditawarkan pada pasar global dapat berasal dari mana saja tanpa mengenal hambatan - hambatan yang berarti pada pasar itu. Dalam kondisi seperti ini, segala bentuk proteksi yang bersifat menghambat mekanisme kerja pasar bebas yang dilandasi persaingan bisnis murni akan tersingkir atau mendapat tekanan- tekanan yang akan menyulitkan mereka yang melakukan proteksi itu.

Kunci persaingan dalam pasar global adalah kualitas total (total quality) yang dalam hal ini telah mencakup penekanan penekanan pada kualitas produk (product quality), kualitas biaya/harga (cost/price quality), kualitas keamanan (safety quality), kualitas pelayanan dan kualitas semangat (moral quality), dan mungkin bentuk bentuk kualitas lainnya yang terus berkembang guna memberikan kepuasan terus menerus kepada pelanggan sehingga menciptakan loyalitas pelanggan.

Berbagai dimensi kualitas jasa atau pelayanan di atas harus diperhatikan oleh manajemen industri jasa, terutama dalam menetapkan biaya yang harus dikeluarkan pelanggan untuk membayar jasa yang diterima. Seyogianya biaya yang ditetapkan harus kompetitif dengan pesaing-pesaing lainnya dalam industri jasa.

Berdasarkan hal diatas, setiap perusahaan harus melakukan perbaikan kualitas terus menerus (continuous quality improvement) agar mampu meningkatkan kepuasan pelanggan. Menyadari kenyataan yang akan dihadapai di era globalisasi, dunia bisnis Indonesia seyogianya membangun sistem kualitas modern agar mampu mempertahankan pelanggan yang telah ada (customer loyality) dan menarik para konsumen (pelanggan potensial) menjadi pelanggan.

PT. Indocement Tunggal Prakarsa, Tbk - Plant 12 Tarjun - Kotabaru - Kalimantan Selatan merupakan pabrik semen pertama yang berdiri di provinsi Kalimantan Selatan dalam usahanya melakukan saluran distrubusi intensif yaitu saluran distrubusi dimana barang yang dipasarkan diusahakan agar dapat menyebar seluas mungkin sehingga dapat secara intensif menjangkau semua lokasi dimana calon konsumen berada ( Indriyo Gitosudarmo dalam Dasar - Dasar Manajemen Pemasaran - Danang Sunyoto, 2014).Dengan kapasitas produksi sebesar 2,6 juta ton per tahun dan melalui saluran distribusi intensif diharapkan mampu menguasai pangsa pasar domestik untuk area luar Jawa dengan merek dagang Tiga Roda dengan produk semen perseroan yaitu Portland Composite Cement (PCC) dengan kemasan Netto $50 \mathrm{Kg}$. Untuk mendukung target marketing tersebut maka pabrik ini telah memiliki 3 unit mesin packer dengan kapasitas 7.500 ton per hari dan juga memiliki 4 dermaga dengan Dead Weight Tonage (DWT) sebesar $750 \mathrm{~s} / \mathrm{d} 5.200$ ton. Dengan fasilitas mesin yang memadai dan sistem manajemen ISO 9000 series yang sudah dimiliki yang didalam ISO 9000 series juga memuat tentang manajemen kualitas (quality management), maka sudah sepantasnya target distribusi semen luar jawa melalui media transportasi kapal laut dapat terpenuhi sesuai budget yang telah ditetapkan oleh bagian marketing.

Berdasarkan data yang diperoleh oleh peneliti diketahui bahwa secara keseluruhan target / budget disribusi tercapai sesuai budget dari Sales \& Marketing Division . Namun peneliti menelaah lebih jauh bahwa terdapat masalah kualitas ( quality problem ) pada sistem distribusi semen sehingga terdapat beberapa kali distribusi semen tidak dapat tercapai sesuai target / budget yang telah ditetapkan oleh Sales \& Marketing Division. Hal ini tentunya menjadi perhatian khusus dari manajemen plant 12 Tarjun. Untuk mengetahui lebih jelas masalah kualitas yang dialami oleh PT. Indocement Tunggal Prakarsa, Tbk Plant 12 Tarjun.

\section{Kajian Literatur}

Dr. Edward Demings, seorang doctor statistic kebangsaan Amerika Serikat yang merupakan pakar kualitas ternama dan yang mengajarkan kepada Jepang tentang konsep pengendalian kualitas, mengemukakan bahwa proses industri harus diapndang sebagai suatu perbaikan kualitas secara terus 
menerus (Continuous Quality Improvement) yang dimulai dari sederet siklus sejak adanya ide untuk menghasilkan suatu produk, pengembangan produk, proses produksi, sampai dengan distribusi kepada pelanggan seterusnya berdasarkan informasi sebagai umpan balik yang dikumpulkan dari pengguna produk ( pelanggan ) dikembangkan ide-ide untuk menciptakan produk baru atau meningkatkan kualitas produk lama beserta proses produksi yang ada saa ini. Continuous Improvement yang diperkenalkan oleh Dr. Edward Deming adalah PDCA (Plan, Do, Check, Action) atau yang biasa dikenal dengan nama Deming's Cycle.

Menurut Syahu Sugian O ( 2006 : 168) dalam Kamus Manajemen Mutu dijelaskan bahwa PDCA Cycle (Siklus Plan - DO Check - Action) adalah empat langkah untuk peningkatan mutu :

1. PLAN : Rencana - rancana organisasi mengenai apa yang dilakukan untuk memasok pelanggan dengan suatu produk atau jasa.

2. $D O$ : Organisasi selanjutnya melakukan apa yang direncakanaknnya pada tahap peratama.

3. $C H E C K$ : Organisasi selanjutnya memeriksa dan melihat apakah hal tersebut telah memenuhi semua persyaratan dari pelanggan.

4. ACTION : Organisasi kemudian membuat perubahan yang sesuai (bila perlu) sehingga ia akan memenuhi persyaratan yang diminta oleh pelanggan di waktu selanjutnya.

Siklus ini kadang kala mengacu pada Shewhart Cycle, karena Walter A.Shewhart mendiskusikan konsep tersebut dalam bukunya Statistical Methode From The Viewpoint Of Quality Control dan mengacu pada Deming Cycle, karena W. Edwards Deming yang memperkenalkan konsep tersebut di Jepang, orang Jepang menyebutnya sebagai Deming Cycle. Siklus kemudian diulang kembali, dan tidak akan berakhir. Hal ini mengakibatkan siklus ini juga diberi nama lain yaitu Continuous Improvement (Continuous Improvement Cycle).
Beberapa pengertian mengenai saluran distribusi oleh pakar di bidangnya sebagai berikut :

1. Menurut Michael J. Etzel dalam Danang Sunyoto ( 2014 : 172 ) menerangkan bahwa saluran distribusi terdiri dari serangkaian lembaga yang melakukan semua kegiatan yang digunakan untuk menyalurkan produk dan status pemiliknya dari produsen ke konsumen akhir atau pemakai bisnis. Distribusi fiksik terdiri dari semua kegiatan yang bertalian dengan pemindahan produkproduk yang tepat, dalam jumlah yang tepat pada waktu yang tepat.

2. Menurut Suhardi Sigit dalam Danang Sunyoto ( 2014 : 172 ) menerangkan bahwa saluran distribusi adalah perantara - perantara, para pembeli, dan penjual yang dilalaui oleh perpindahan barang baik fisik maupun perpindahan milik sejak dari produsen hingga ke tangan konsumen.

3. Menurut Kotler ( 2002 : 558 ) bahwa saluran pemasaran adalah serangkaian organisasi yang saling tergantung dan tidak terlibat dalam proses untuk menjadikan produk atau jasa siap untuk digunakan atau dikonsumsi.

Semen merupakan bahan pengikat hidrolis berupa bubuk halus yang dihasilkan dengan cara menghaluskan clinker dengan batu gips sebagai bahan tambahan (Dr. Wuryati Samekto, Mpd dan Chandra Rahmadiyanto, $2001: 33$ ).

Menurut Bonardo Pangaribuan dalam Manual Book Bulk Loader Handling Holcim (2004 : 48) mengatakan bahwa semen berasal dari bahasa latin caementum yang berarti bahan perekat atau dapat didefinisikan sebagai bahan perekat atau lem yang dapat merekatkan baha-bahan material lain seperti batu bata dan batu koral hingga bisa membentuk sebuah bangunan, sedangkan pengertian secara umum semen diartikan sebagai bahan perekat yang memiliki sifat mampu mengikat bahan-bahan padat menjadi satu kesatuan yang kompak dan kuat.

Erwin Irianto Siahaan (2011) dalam penelitiannya berjudul "Perencanaan Perbaikan dan Peningkatan Kualitas Dengan 
Menerapkan Pendekatan Metode Kaizen Pada Proses Raw Mill Produk Ordinary Portland Cement Di PT. Indocement Tunggal Prakarsa, Tbk". Metode yang digunakan metode penelitian deskriptif dengan pendekatan yang digunakan adalah pendekatan kuantitatif.

Berdasarkan penelitian dan pengolahan data dari penelitian terdahulu, maka penulis dapat menyimpulkan bahwa dengan menggunakan metode Kaizen - Pendekatan PDCA ( Deming Cycle) maka permasalahan kualitas (quality problem) dalam hal proses produksi tepung baku semen (raw meal) dapat dikendalikan dengan baik sehingga penyimpangan kualitas dapat dihilangkan. Penelitian dimulai dari tahapan perencanaan (Plan) dengan cara melakukan identifikasi permasalah terhadap proses produksi tepung baku semen dengan hasil diketahui bahwa penyebab adanya kegagalan adanya gangguan pada mesin weight feeder dengan tingkat permasalahan yang terjadi sebesar $37 \%$.Dengan menggunakan analisa pareto maka ditemukan breakdown dari permasalahan yaitu berupa penyebab terjadinya ketidaksesuaian terhadap alat weight feeder adalah terjadinya penyimpangan modulus LSF dengan tingkat permasalahan sebesar $73 \%$. Penyebab ini diperbaiki dengan menggunakan alat bantu Kaizen 5W2H . Melalui alat bantu 5W2H maka ditentukanlah perbaikan - perbaikan dari 4 faktor, yaitu dari faktor manusia, mesin, metode dan lingkungan.

Penyebab dari faktor manusia adalah kurangnya pengawasan dan kesalahan setting point, penyebab ini diperbaiki dengan cara dibuatnya lembar pengawasan dalam bekerja dan instruksi kerja yang jelas.Penyebab dari faktor mesin ada pada tidak optimalnya meisn weight feeder dan raw grinding mill, maka untuk penyebab ini dilakukan perbaikan berupa pemeriksaan secara berkala.Penyebab faktor metode ada pada teknik penumpukan bahan baku dan dilakukan perbaikan dengan cara merubah metode penumpukan menjadi metode continuous stock pilling. Dari faktor lingkungan karena tidak lancarnya material dan debu yang bercampur dengan bahan baku, penyebab ini diperbaiki dengan cara membuat jalur hubung debu menuju penampungan batu kapur. Dari 4 perbaikan maka dapat dihasilkan tidak terjadi lagi gangguan pada proses produksi raw mill dengan tingkat keberhasilan $100 \%$.

Berdasarkan pada serangkaian teori dan penelitian terdahulu yang telah dikemukakan, maka dapat disusun model kerangka berfikir dari penelitian ini seperti ditunjukkan pada gambar 1.

Gambar 1 menceritakan tentang bagaimana perbaikan kualitas proses bisnis harus dilakukan secara menyeluruh mulai dari imput hingga output. Perbaikan kualias input sangat dipengaruhi dari kualitas pemasok bahan baku dan fasilitas produksi, sedangkan kualitas output sangat berkaitan dengan preferensi dari pelanggan. Hal ini kemudian menjadi pedoman dalam membuat analisis demings cycle untuk mengatasi masalah kualitas, dengan menjadikan kebutuhan konsumen dan kepuasan pelanggan sebagai tolok ukur kualitas. Jadi dapat disimpulkan bahwa PLAN berkaitan dengan proses mengidentifikasi masalah, DO berkaitan dengan analisis penyebab permasalahan dan upaya perbaikan yang dilakukan, CHECK berkaitan dengan evaluasi dari upaya perbaikan yang dilakukan, dan ACTION merupakan pelaksanaan dari standari baru yang dibuat berdasarkan hasil evaluasi.

\section{Metode Penelitian}

Metodologi yang digunakan untuk memecahkan permasalahan kualitas dalam upaya peningkatan proses perbaikan berkelanjutan dalam manajemen mutu yang terdiri dari Plan (Perencanaan) Do (Pelaksanaan) Check (Pengontrolan) Action (Tindaklanjut) . Dalam prakteknya penerapan metodologi Deming Cycle dapat dibagi menjadi beberapa tahapan / langkah seperti yang tertera pada penjelasan sebelumnya, ada yang menggunakan PDCA 6 langkah, ada yang menggunakan PDCA 7 langkah, ada juga yang menerapkan PDCA 8 langkah, bahkan ada yang menggunakan PDCA menjadi 12 langkah.Namun peneliti akan menggunakan PDCA Deming Cycle 7 langkah untuk dapat meningkatkan distribusi semen. 
MODEL PERBAIKAN KUALITAS PROSES BISNIS

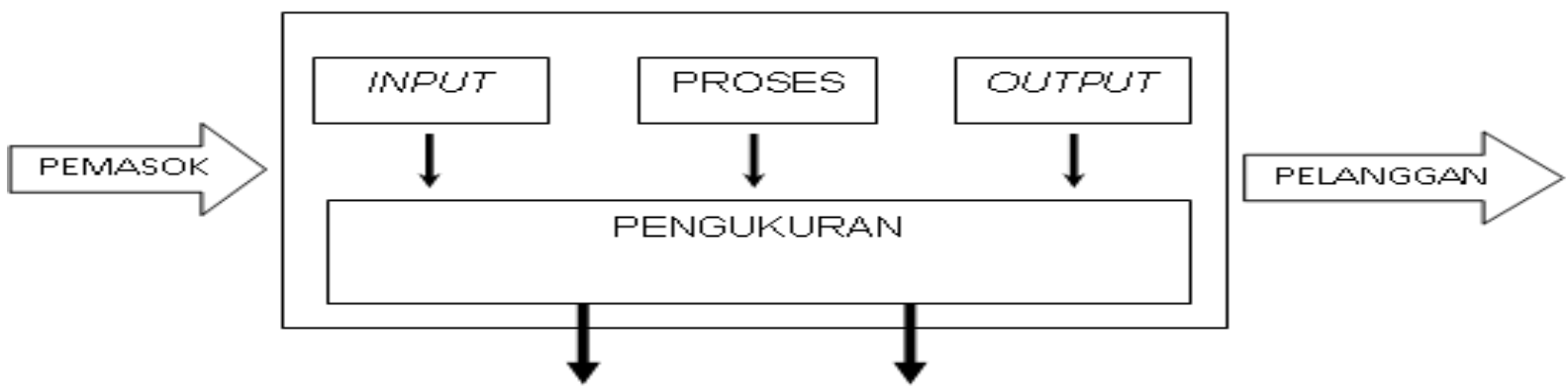

PLAN

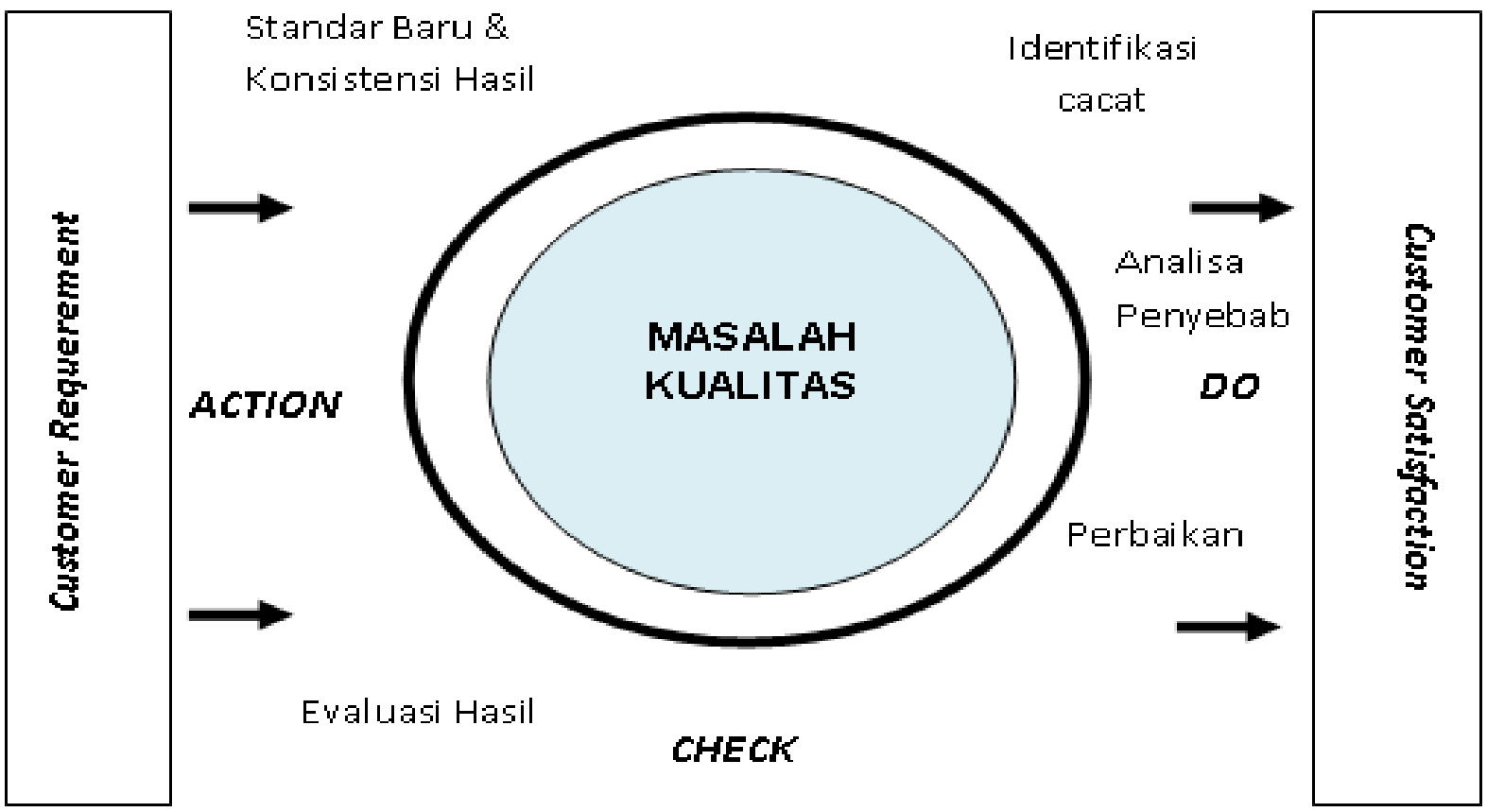

Gambar 1. Kerangka Berpikir Penelitian

Jenis data yang digunakan dalam penelitian ini adalah data kualitatif dan data kuantitatif. Data kualitatif adalah data yang bukan dalam bentuk angka-angka atau tidak dapat dihitung, dan diperoleh dari hasil wawancara dengan pimpinan perusahaan dan karyawan dalam perusahaan serta informasiinformasi yang diperoleh dari pihak lain yang berkaitan dengan masalah yang diteliti. Data kuantitatif adalah data yang diperoleh dalam bentuk angka-angka yang dapat dihitung, yang diperoleh dari kuesioner yang dibagikan ataupun laporan - laporan yang sudah tersedia dan berhubungan dengan masalah yang diteliti.

Sumber data penelitian berasal dari sumber primer dan sumber sekunder. Data primer adalah data yang diperoleh penulis melalui observasi atau pengamatan langsung dari perusahaan, baik itu melalui observasi, kuesioner dan wawancara secara langsung dengan pimpinan dan staf perusahaan atau karyawan sesuai dengan kebutuhan dalam penelitian. Data sekunder adalah data yang sudah tersedia di objek peneltian dan langsung dapat digunakan oleh peneliti, data tersebut diperoleh dari dokumen-dokumen perusahaan serta buku-buku literatur yang memberikan informasi tentang peralatan / mesin distribusi semen.

Data adalah sumber informasi yang penting untuk kelancaran proses penelitian. Pada penelitian ini data dikumpulkan dengan 
menggunakan teknik pengumpulan data sebagai berikut :

1. Studi Lapangan(Field Research), yaitu dikumpulkan dengan cara interview (wawancara), yaitu mengadakan wawancara kepada pihak manajemen dan karyawan perusahaan yang berkaitan dengan masalah yang diteliti, dan observasi (tinjauan lapangan), yaitu dengan mengadakan penelitian secara langsung dilapangan, penelitian ini guna memperoleh data yang akurat.

2. Dokumenter (dokumentasi), yaitu menggali data dari sumber tertulis yang dimiliki oleh PT. Indocement Tunggal Prakarsa, Tbk Plant 12 Tarjun Kotabaru Kalimantan Selatan sehubungan dengan masalah yang diteliiti.

Teknik analisa data yang digunakan adalah teknik analisa deskriptif dari data yang diperoleh nantinya, akan dianalisa melalui angka - angka dan diagram diagram sesuai variabel yang ditentukan dengan menggunakan dasar-dasar teoritis, kemudian akan ditarik kesimpulan dan saransaran yang diperlukan untuk memperbaiki dan mengatasi permasalahan dalam proses identifikasi masalah distribusi semen yang dilakukandi PT Indocement Tunggal Prakarsa Tbk. Plant 12 Tarjun Kabupaten Kotabaru Kalimantan Selatan. Kesemuanya akan dikemas dalam satu metodologi PDCA Tujuh Langkah \& Tujuh Alat Bantu (TULTA).

\section{Hasil Penelitian Dan Pembahasan}

Berdasarkan uraian hasil penelitian diatas tampak bahwa PT. Indocement Tunggal Prakarsa,Tbk Plant 12 Tarjun dalama mengatasi permasalahan distribusi semen yang tidak mencapai target marketing menggunakan Deming Cycle dengan metodologi PDCA Tujuh Langkah dan Tujuh Alat Bantu ( TULTA ) ternyata terfokus melalui penekanan pada gangguan peralatan yang menyebabkan terhentinya proses pengiriman semen sehingga target marketing tidak tercapai. Adapun tahapan dalam penerapan Deming Cycle pada permasalahan kualitas proses distribusi semen bag via laut masih ditemukan beberapa defect yang akan dijelaskan pada alinea-alinea selanjutnya.

Tahapan yang pertama adalah PLAN ( Perencanaan ). Solusi untuk mengatasi berbagai permasalahan kualitas yang menghasilkan berbagai defect, harus diawali dari perencanaan yang baik, meliputi:

1. Pembentukan Gugus Kendali Mutu .

Untuk mengatasi permasalahan kualitas dalam hal terdapat gangguan pada distribusi semen bag via laut maka tahap awal yang harus dilakukan dalam perencanaan adalah membentuk kelompok kerja karyawan untuk melakukan problem solving terhadap masalah kualitas distribusi semen bag via laut, dengan nama kelompok karyawan tersebut dikenal dengan istilah Gugus Kendali Mutu. Pembentukan Gugus Kendali Mutu dilakukan dalam rangka untuk melaksanakan pemecahan masalah tidak tercapainya distribusi semen sesuai harapan / target marketing dengan metodologi PDCA TULTA maka diperlukan team work sesuai penunjukan dari pimpinan lini. Penunjukan team yang akan melakukan penelitian diambil dari bagian Dispatch Department yang merupakan sumber masalah berada tanpa dilakukan penelitian atau analisa permasalahan terlebih dahulu. Hal ini akan berdampak pada keterbatasan team ketika akan melakukan perbaikan . Hasil penelitian dari penulis bahwa akan sangat tepat ketika pemilihan team berdasarkan analisa PDCA TULTA terhadap permasalahan ini dimulai dari menelaah penyebab tidak terkirimnya semen bag via laut yang disebabkan karena gangguan peralatan. Berdasarkan analisa pareto bahwa gangguan peralatan yang paling dominan adalah pada gangguan komputerisasi loading system yaitu sistem pada komputerisasi untuk melakukan pemuatan. Dengan demikian maka ditentukanlah kelompok atau tim yang menangani masalah ini adalah berasal dari bagian Management Information System \& Collecting Data yang berada dibawah General Manager Operation pada struktur organisasi bukan berasal dari Dispatch Department yang merupakan departemen 
yang memiliki masalah mutu. Gugus Kendali Mutu adalah sekelompok karyawan yang terdiri dari minimum 5 orang atau lebih yang mengadakan penelitian dan pemecahan masalah yang terjadi pada lini masing- masing guna meningkatkan performance di bagiannya masing-masing. Adapun Tim yang dipilih ini diberi nama Gugus Kendali Mutu ( GKM ) DATA.

2. Pembuatan Jadwal Kegiatan

GKM Data mengawali kegiatan penelitiannya dengan menyusun jadwal kegiatan penelitian dengan menggunakan alat bantu Gant Chart seperti pada tabel 3.2. Jadwal yang disusun mencangkup :

a. Langkah Kegiatan PDCA TULTA.

b. Waktu pelaksanaan kegiatan.

Penjelasan :

Dalam pembuatan rencana kegiatan dalam bentuk jadwal yang tertera di dalam gant chart, GKM Data mengawali kegiatan dengan menentukan proses PDCA dengan Plan terlebih dahulu pada langkah 1 yaitu Menentukan Tema \& Judul yang direncanakan pada minggu ke III bulan Nopember tahun 2016. Untuk langkah ke II pada Plan yaitu Menganalisa Penyebab, GKM Data menentukan rencana kegiatan pada minggu ke IV bulan Nopember tahun 2016. Sedangkan pada langkah ke III masih dari rangkaian Plan, ditentukanlah rencana kegiatan juga pada minggu Ke IV tahun 2016. Melangkah ke tahapan DO pada PDCA, maka GKM data mengawalinya dengan merencanakan kegiatan pada minggu I s/d IV Desember tahun 2016 untuk Membuat Rencana dan Melaksanakan Perbaikan. Dalam Meneliti Hasil yang merupakan tahapan CHECK pada PDCA, maka GKM Data merencanakan kegiatan pada minggu I s/d IV Januari 2016. Sedangkan pada tahapan akhir dari PDCA yaitu Action, maka GKM Data merencanakan kegiatan pada minggu I bulan Pebruari tahun 2016 untuk langkah VI yaitu Membuat Standar Baru dan minggu II Pebruari tahun 2016 untuk kegiatan kegiatan langkah VII yaitu
Mengumpulkan Data Baru \& Menentukan Rencana Berikutnya.

3. Identifikasi Masalah

Dalam melakukan identifikasi permasalahan kualitas, GKM DATA sudah mengawali Langkah 1 dalam 7 langkah PDCA yaitu Menentukan Tema \& Judul. Didalam menentukan tema dan judul yang pertama dilakukan adalah identifikasi permasalahan kualitas (quality problem). Permasalahan kualitas yang diangkat adalah bersumber dari:

a. Aspek mutu Delivery yaitu deviasi / penyimpangan terhadap pengiriman berupa keterlambatan pengiriman. Hal ini terlihat pada gangguan yang terjadi pada pengiriman semen bag via laut karena kerusakan pada Bag Counting System yang merupakan sistem penghitungan komputerisasi semen bag via laut dengan lama gangguan 24 jam sehingga dapat diartikan semen bag terlambat terkirim ke pelanggan selama 24 jam di tahun 2015.

b. Permasalahan yang berasal dari objective departemen yang tidak tercapai. Terdapat semen bag via laut yang gagal terkirim di tahun 2015 sebanyak 407.425 ton atau sebesar $81,23 \%$ dari target sebanyak 2.171 .000 ton hanya terkirim sebanyak 1.763 .575 ton. Dari hasil analisa juga diketahui bahwa loss product akibat gangguan bag counting system sebesar 1.800 ton yang gagal terkirim di tahun 2015 yang berakibat kerugian senilai Rp. 1.980.000.000,-. Proses Breakdown penentuan tema dan judul yang merupakan gambaran permasalahan tidak dilakukan oleh GKM Data dengan metodologi sebelumnya, mereka hanya menentukan masalah global yang akan ditangani yaitu gangguan pada loading system. Dengan analisa breakdown terhadap masalah maka GKM lebih focus kepada hasil analisa masalah yang lebih mudah untuk dijangkau/lebih focus yaitu masalah pada Bag Counting System. Masih dalam pembahasan langkah I dalam melakukan identifikasi masalah , 
dengan metodologi yang lama tidak dilakukan pengukuran terhadap dampak perbaikan terhadap team dan departemen terkait namun dengan metodologi baru penulis mengarahkan kepada gugus bahwa setelah gugus menganalisa terhadap masalah kualitas yang di hadapi Dispatch Departemen, maka selanjutnya adalah analisa terhadap dampak dari perbaikan terhadap anggota dan lini, apakah kegiatan perbaikan ini berpengaruh terhadap masing - masing personal anggota GKM Data dan berpengaruh terhadap Dispatch Departemen ? hal ini akan diketahui dengan cara mengukurnya melalui alat bantu Radar Chart. Parameter pengukuran adalah Kinerja QCC ( GKM ) dan Mutu Lokasi Kerja. Pengukuran Kinerja $Q C C$ dilakukan dengan tujuan untuk mengetahui bagaimana kinerja $Q C C$ sebelum melakukan aktivitas penelitian ini. Adapun para meter yang diukur pada masing - masing anggota adalah sbb :

- Konsep Dasar Mutu \& Peningkatan Mutu.

- Aktivitas $Q C C$ \& Peranan Anggota.

- Penerapan PDCA Tulta \& Tool's.

- Pengembangan Keterampilan \& Talenta.

- Motivasi penembangan Diri.

GKM Data mempunyai nilai rata - rata sebesar 2,5 yang artinya dalam penerapan ke 5 parameter tadi masih dinilai kurang.

c. Pengukuran Mutu Lokasi Kerja dilakukan dengan tujuan untuk mengetahui seberapa besar manfaat penelitian melalui $Q C C$ ini bagi perusaaan atau lini masing-masing baik sebelum perbaikan maupun sesudah perbaikan. Adapun para meter yang diukur pada masing - masing anggota adalah sbb :

- Hubungan Kerja dan Team Work.

- Frekuensi \& Mutu Pertemuan.

- Kerjasama Atasan \& Bawahan.
- Motivasi Peningkatan Pengetahuan \& Keterampilan.

- Konsistensi Pelaksanaan SDCA \& Program 5S.

GKM Data mempunyai nilai rata - rata sebesar 2,5 yang artinya dalam penerapan ke 5 parameter tadi masih dinilai kurang.

d. Selanjutnya dalam pengukuran Kinerja QCC dan Mutu Lokasi Kerja akan dianalisa dengan menggunakan Rinda Window untuk mengetahui posisi etalase kemampuan yang ada dari GKM Data pada saat sebelum perbaikan dengan alat bantu Radar Chart. Berikut hasil analisa dari GKM Data sbb :

- Kinerja $Q C C$ yang sudah diukur merupakan indicator yang diletakkan pada sumbu $\mathrm{X}$ dari radar chart.

- Mutu Lokasi Kerja yang sudah diukur merupakan indicator yang diletakkan pada sumbu Y dari radar chart.

- Kinerja $Q C C$ mempunyai nilai rata - rata 2,5.

- Mutu Lokasi Kerja mempunyai nilai rata - rata 2,5.

- Pertemuan antara sumbu X dan sumbu Y berada pada Jendela Zona $\mathrm{C}$ yang mengandung arti bahwa mutu kerja sudah melalui PDCA tetapi belum berhasil optimal.

3. Presentasi Dengan Manajemen.

Setelah melalui proses penilaian terhadap kinerja $Q C C$ dan mutu lokasi kerja, selanjutnya GKM Data melakukan presentasi di hadapan manajemen untuk memamaparkan hasil analisa pada identifikasi masalah (langkah I). Dalam menentukan tema \& judul Dalam presentasi banyak interaksi \& diskusi antara GKM Data dengan manajemen. Setelah selesai maka komentar manajemen yang berisi ajakan atau saran untuk tindaklanjut dibubuhkan dalam makalah dan ditandatangani sebagai bentuk komitmen manajemen dalam 
mendukung kegiatan penelitian perbaikan ini.

4. Menganalisa Penyebab.

Permasalahan yang dihadapi oleh GKM data tertuang dalam judul penelitian perbaikan yaitu gangguan Bag Counting System Lama / Tinggi. Untuk mengetahui apa penyebab terjadinya permasalahan maka GKM Data akan melakukan diskusi tanpa tahu teknik dalam mencari penyebab, penulis mencoba mengarahkannya dengan melakukan teknik Brainstorming (sumbang saran) yang merupakan alat bantu dalam mencari penyebab dari permasalahan. Dipimpin oleh Ketua GKM maka disepakati bahwa brainstorming dilakukan dengan cara setiap anggota akan diberikan pertanyaan mengapa gangguan bag counting system tinggi secara bergantian, dengan menggunakan teknik 5 why maka setiap anggota menghasilkan data yang dapat dianalisis lebih lanjut.

Hasil dari brainstorming ini akan dilakukan stratifikasi (pengelompokkan) kedalam format 4M1E (Man, Methode, Material, Machine, Environment ). Dengan alat bantu Ishikawa diagram untuk pemetaan sebab akibat dari permasalahan maka diketahuilah akar akar penyebab dari masing-masing $4 \mathrm{M} 1 \mathrm{E}$ yang dijadikan dasar dalam penentuan nilai Nominal Group Technique (NGT). GKM Data Belum mengatehui tekhnik dalam menggunakan alat bantu maka dari itu penulis mengarahkan dan menjelaskan GKM Data tentang NGT. NGT diperlukan untuk menentukan akar penyebab yang dominan akan ditindaklanjuti dilangkah berikutnya. Adapun cara memperoleh nilai NGT adalah sbb :

- Semua anggota dengan dipimpin oleh ketua memberikan nilai dari masing masing penyebab sesuai pendapatnya masing-masing terhadap pemikiran mana saja penyebab yang berpengaruh terhadap terjadinya masalah. Nilai ditentukan mulai dari angka tertinggi sampai dengan angka terendah berdasarkan jumlah banyaknya penyebab.

- Setelah penilaian dilakukan oleh semua anggota GKM Data maka nilai terebut dijumlahkan dan ditentukan level penyebab berdasarkan jumlah nilai.

- Dari urutan level penyebab maka ditentukanlah penyebab-penyebab yang akan ditindaklanjuti dengan menggunakan rumus NGT sbb :

- Jika penyebab - penyebab dominan / akar penyebab berjumlah antara $1 \mathrm{~s} / \mathrm{d}$ 5, maka semua penyebab akan ditindaklanjuti.

- Jika penyebab - penyebab dominan / akar penyebab berjumlah 6 s/d 10, maka penentuan tindaklanjuti menggunakan rumus $1 / 2 \mathrm{~N}+1$.

- Jika penyebab - penyebab dominan / akar penyebab lebih dari 10, maka penentuan tindaklanjut menggunakan rumus $\mathrm{N}+1$.

Maka ditentukanlah penyebab - penybab yang diduga dominanmenyebabkan gangguan bag counting system tinggi adalah sbb :

a. Program quantity manual.

b. Program tidak bisa switch kade kapal.

c. Data kapal tidak tampil.

d. Pindah packer.

e. Delete DO.

f. Shipment lama belum di clossing.

g. Petugas Bag Counting

BelumMengetahui Cara. Mendapatkan Gambaran Masalah.

h. Server Error.

5. Menguji dan Menentukan Penyebab Dominan.

8 akar penyebab yang sudah ditentukan yang merupakan dugaan penyabab akan dilakukan uji hipotesa, apakah benar 8 dugaan penyebab tersebut benar - benar mengakibatkan gangguan bag counting system tinggi ?. Untuk mengetahuinya maka GKM Data yang harus melakukan pengukuran dengan melakukan pengamatan langsung, namun GKM Data belum mengetahui tekhnik pengujian data, maka penulis mengarahkan dan mengajarkan tekhnik menguji dan 
menentukan uji hipotesa dengan langkahlangkah sbb :

a. Lakukan pembagian tugas untuk melakukan pemantauan uji coba sebagai dasar penghitungan melalui data yang didapatkan minimum 7 kali pemantauan atau 7 data.

b. Hitung data yang didapatkan dengan menggunakan rumus berikut :

$$
\mathbf{r}=\frac{\operatorname{n.SumXY}-(\operatorname{Sum} X)(\operatorname{Sum} Y)}{\sqrt{\left[\mathrm{n} \cdot \operatorname{Sum} X^{2}-(\operatorname{Sum} X)^{2}\right]\left[n \cdot \operatorname{Sum} Y^{2}-(\operatorname{Sum} Y)^{2}\right]}}
$$

Terdapat 8 penyebab dominan yang terbukti melalui pengujian hipotesa bahwa penyebab tersebut mengakibatkan terjadinya gangguan bag counting system tinggi. Penyebab tersebut akan ditindakalnjuti dengan membuat perbaikan.

Tahapan yang kedua adalah $D O$, yaitu tahapan Pelaksanaan Perbaikan yang terdiri dari :

1. Membuat Rencana Perbaikan.

Sebelum perbaikan dilakukan maka terlebih dahulu membuat rencana perbaikan dengan menggunakan alat bantu $5 \mathrm{~W} 2 \mathrm{H}$, untuk menjelaskan alat bentu tersebut maka akan dijelaskan berdasarkan salah satu penyebab yang dijadikan sebagai contoh, dengan penjelasan sbb :

a. Why bermakna mengapa program quantity manual harus diperbaiki ? jawaban dari pertanyaan tersebut adalah agar sistem penghitungan tidak mengalami selisih.

b. What bermakna apa bentuk perbaikannya ? jawaban dari pertanyaan tersebut adalah membuat program quantity otomatis Where bermakna kapan perbaikan itu akan dilaksanakan ? jawabannya adalah perbaikan dilaksanakan di kantor MISCD. When bermakna kapan perbaikan itu akan dilaksanakan ? jawaban dari pertanyaan tersebut adalah pelaksanaan perbaikan akan dilaksanakan pada tanggal 05 s/d 14 Desember 2016. Adapun pertanyaan atas Who yang bermakna siapa penanggung jawab dari perbaikan dapat dijawab dengan nama anggota yaitu bapak Husni Thamrin. Pertanyaan selanjutnya adalah How yang bermakna bagaimana cara perbaikan dilakukan ? jawabannya dengan menyebutkan langkah-langkah dalam perbaikan adapun pertanyaan How Much dijawab dengan menyebutkan berapa persen peluang perbaikan ini dapat dilaksanakan.

2. Presentasi dihadapan Manajemen.

Presentasi ini dilakukan dengan maksud untuk menyampaikan rencana perbaikan agar mendapatkan izin dalam melakukan proses perbaikan dikarenakan dalam proses perbaikan selalu berhubungan dengan batasan wewenang dan tanggung jawab, keperluan biaya dan material , standar kesalamtan kerja, waktu pelaksanaan, dan sebagainya. Presentasi dilakukan dihadapan para staff, kepala bagian, kepala departemen.

3. Melaksanakan Perbaikan

Proses pelaksanaan perbaikan dilakukan melalui serangkaian program yang harus segera dibuat, yaitu:

a. Program Quantity Otomatis.

Program ini harus dibuat mengingat program yang ada selama ini bersifat manual, yaitu jumlah / quantity muatan pada dokumen Delivery Order diinput ke dalam sistem komputerisasi secara manual / di ketik langsung ke dalam tabulasi yang sudah tersedia. Hal ini berpotensi terjadi selisih dalam sistem penghitungan muatan yang berakibat akan terjadi salah penghitungan muatan dan berakibat sistem penghitungan error sehingga sistem loading dihentikan. Hal ini yang membuat pemuatan jadi terhambat dan target pengiriman tidak terpenuhi. Dengan dibuatnya program quantity otomatis pada tanggal 05 Desember 2016 dengan cara membuka quantity application kemudian buka D.O. application dilanjutkan dengan membuat link automaticly dan simpan 
link ke program aplikasi bag counting yang kesemuanya dilakukan oleh bapak Husni Tahmrin, maka sistem penghitungan tepat dan benar sehingga perhitungan packing normal dan loading lancer. Hal ini dibuktikan dengan hasil monitoring terhadap pengukuran frekuensi selisih perhitungan selama 8 kali pemantauan dalam 8 hari dengan hasil tidak ditemukan lagi data perhitungan yang mengalami selisih, sehingga GKM Data menyimpulkan perbaikan yang telah dilakukan berhasil.

b. Program Aplikasi Kade Kapal Alternatif.

Program ini harus dibuat mengingat program yang ada tidak bisa switch kade kapal sehingga program kade tidak bisa dihentikan berakibat program shipment tidak bisa di closing dan program harus dimatikan anprosedur yang berakibat bag counting program rusak. Hal ini yang membuat pemuatan jadi terhambat dan target pengiriman tidak terpenuhi. Dengan dibuatnya program aplikasi kade kapal alternatif yang dilakukan oleh bapak Hendra Adiwijaya pada tanggal 05 Desember 2016, dengan diawali membuka berthing aplikasi kemudian membuka berthing line dilanjutkan dengan menambahkan line $\mathrm{X} 1, \mathrm{X} 2$ dan $\mathrm{X} 3$ sebagai kade alternatif dan simpan data line ke program aplikasi bag counting., maka program switch kade kapal dapat dilaksanakan sehingga program kade bisa dihentikan maka program shipment pun dapat diclossing dan program dapat dimatikan sesuai prosedur sehingga program bag counting berjalan dengan lancar. Hal ini dibuktikan dengan hasil monitoring terhadap pengukuran frekuensi program shipment tidak bisa diclossing 9 kali pemantauan dalam 9 hari dengan hasil tidak ditemukan lagi program shipment tidak bisa diclose, sehingga GKM Data menyimpulkan perbaikan yang telah dilakukan berhasil. c. Program Database Kapal.

Program ini dibuat dikarenakan sering terjadi data kapal tidak tampil sehingga data D.O. tidak dapat di registrasi yang mengakibatkan data berthing line tidak dapat diproses sehingga data loading tidak lengkap dan data bag counting tidak dapat diproses. Hal ini yang membuat pemuatan jadi terhambat dan target pengiriman tidak terpenuhi. Program Database kapal dibuat oleh bapak Husni Thamrin pada tanggal 16 Desember 2016 dengan langkah langkah sbb :

- Buka aplikasi vessel status .

- Buka aplikasi delivery.

- Link data vessel status.

- Simpan data line ke program aplikasi bag counting system.

Setelah perbaikan ini kemudian dilakukanlah pemantauan terhadap perbaikan dari tanggal 17 s/d 30 Desember 2016 terhadap data berthing line tidak dapat diproses dengan hasil selama 5 hari pemantauan diketahui bahwa tidak ada lagi data berthing line tidak dapat diproses, dengan kata lain semua data berthing dapat diproses sehingga data loading menjadi lengkap yang berakibat data bag counting dapat diproses. . Sehingga GKM Data menyimpulkan perbaikan yang telah dilakukan Berhasil.

\section{d. Program Aplikasi Back Up Kode Packer.}

Frekuensi pindah packer yang tinggi mengakibatkan kode packer berubah sehingga terjadi penggantian terhadap kode packer akibatnya terjadi ganti jalur packer dan aplikasi pakcerpun terpaksa harus diganti. Hal ini yang membuat pemuatan jadi terhambat dan target pengiriman tidak terpenuhi. Hal ini juga yang membuat bapak Hendra Adiwijaya membuat program aplikasi back up kode pakcer pada tanggal 13 Desember 2016 dengan cara terlebih dahulu membuka program bag counting system kemudian membuka aplikasi packer dan input data packer, 
lalu dilanjutkan dengan klik aplikasi TR ( Translate) dang anti berthing line code lalu klik kode packer yang akan dipindah. Dengan demikian kode packer tetap dan tidak perlu ganti kode packer sehingga tetap dapat menggunkan jalur packer yang sama dan aplikasi packer yang sama. Selanjutnya pemantauan dilakukan terhadap perbaikan, yaitu pada tanggal 14 s/d 16 Desember 2016 dengan 5 kali pemantuan terhadap indicator $\mathrm{Y}$ berupa frekuensi kode packer berubah dengan hasil pemantauan bahwa tidak ada lagi kode packer yang berubah sehingga GKM data menyatakan bahwa perbaikan telah Berhasil.

\section{e. Program Link Database.}

Pembuatan program link database dikerjakan oleh bapak Hendra Adiwijaya pada tanggal 19 Desember 2016. Hal ini dilakukan karena D.O. terdelete oleh petugas sehingga D.O. hilang yang berakibat D.O. tidak terdaftar dalam komputerisasi sehingga D.O. tidak dapat diupload ke sistem selanjutnya yang berakibat pada D.O. tidak dapat dikeluarkan. Perbaikan dilakukan dengan cara membuka aplikasi vessel name kemudian membuka data share D.O. lalu klik kode D.O. dan input nomor master D.O. Setelah master D.O. terinput maka dilanjutkan dengan input data nomor Sub D.O. dan kemudian data dapat disave. Hal ini dilakukan agar D.O tidak terdelete sehingga D.O. tetap berada pada database dan terdaftar sehingga dapat diupload ke sistem berikutnya dan D.O. dapat dikeluarkan sehingga pemuatan menjadi lancar dan target pemuatan dapat terpenuhi. Seperti pada perbaikan - perbaikan sebelumnya bahwa setelah perbaikan dilakukan pemantauan atau monitoring terhadap perbaikan yang dilakukan. Bapak Hendra melakukan pemantauan sejak tanggal 20 s/d 23 Desember 2016 terhadap frekuensi D.O. hilang. Hasil pemantauan menyatakan bahwa tidak aa lagi D.O. hilang selama 6 kali pemantauan, sehingga GKM Data menyimpulkan bahwa perbaikan ini Berhasil.

f. Program Clossing Shipment.

GKM Data harus membuat program closing shipment dikarenan terjadi kondisi dimana shipment lama belum diclossing sehingga aplikasi shipment error yang mengakibatkan shipment list tidak tampil sehingga shipment tidak dapat diupload yang pada akhirnya display shipment menjadi kosong. GKM Data melalui bapak Hendra Adiwijaya melakukan perbaikan membuat program closing shipment pada tanggal 26 Desember 2016 dengan cara membuka bag counting system terlebih dahulu, kemudian klik aplikasi vessel status lalu klik aplikasi shipment closing, kemudian klik vessel name dan mengclose aplikasi shipment. Monitoring dilakukan pada tanggal 27 s/d 30 Desember terhadap frekuensi shipment list tidak tampil. Hasil monitoring terhadap pengukuran frekuensi shipment list tidak tampil selama 5 hari pemantauan adalah tidak adalagi frekuensi shipment list tidak tampil, shipment list selalu tampil dan dapat diupload sehingga display shipment selalu tampil pada monitor hal ini berakibat pada lancarnya pemuatan dapat berpengaruh terhadap target pengiriman, dengan demikian perbaikan ini dintyatakan oleh GKM Data Berhasil.

\section{g. Program Link Capture Masalah.}

Berdasarkan analisa penyebab diketahui bahwa petugas bag counting belum mengetahui cara mendapatkan gambaran masalah sehingga petugas bag counting tidak dapat memberikan gambaran titik permasalahan hal ini berakibat petugas MIS tidak mendapatkan gambaran masalah dari petugas bag counting sehingga petugas MIS tidak mengetahui letak permasalahan yang sebenarnya sehingga petugas MIS tidak dapat 
mengatasi masalah kerusakan bag counting dan hal ini dapat menghambat pemuatan sehingga target tidak tercapai. Untuk penyebab ini, GKM Data sepakat bahwa tindakan perbaikan yang diambil adalah membuat program link capture yang dilaksanakan oleh ibu Dini Wardini pada tanggal 25 Desember 2016 dengan membuka $e$ mail aplikasi kemudian membuka bag counting system dilanjutkan dengan penjelasan tentang masalah lalu tekan tekan Alt + Printscreen pada display bag counting system kemudian buka kembali e-mail lalu klik menu paste pada display e-mail dan send e-mail ke petugas MIS. Perbaikan ini dimonitoring pada tanggal 26 s/d 30 Desember 2016 terhadap durasi petugas MIS mengatasi masalah dan didapat hasil bahwa selama 6 hari pemantauan durasi petugas MIS mengatasi masalah rata-rata selama 5 menit yang sebelumnya ketika perbaikan belum dilaksanakan durasi petugas MIS mengatasi masalah hingga mencapai 30 menit. Berdasarkan hasil ini maka mengatasi permasalahan lebih cepat karena petugas bag counting sudah mengetahui cara mendapatkan gambaran masalah dengan cepat sehingga petugas bag counting dapat memberikan gambaran titik permasalahan dan petugas MIS mengetahui gambaran masalah dari petugas bag counting sehingga petugas MIS mengetahui letak permasalahan sesungguhnya dan dapat mengatasi kerusakan pada bag counting yang mengakibatkan pemuatan menjadi lancar dan target dapat tercapai. GKM Data meyimpulkan bahwa perbaikan ini Berhasil.

\section{h. Program Reset Server Error.}

Gangguan pemuatan semen bag via laut juga terjadi ketika server mengalami error yang mengakibatkan data produksi tidak tampil sehingga data semen yang masuk tidak dapat diketahui dan berakibat pada data perhitungan tidak akurat sehingga data harus direset yang pada akhirnya hal ini menjadi salah satu penyebab pengiriman tidak tercapai. Oleh karena itu GKM Data melalui ibu Aan Nayuri melakukan perbaikan pada tanggal 25 Desember 2016 dengan cara membuat program reset server error dengan cara dahulu membuka bag counting program kemudian remote bag counting program lalu reset radio komunikasi. Berdasarkan monitoring melalui pengukuran terhadap frekuensi data produksi tidak tampil selama 6 hari pemantauan diketahui bahwa tidak ada lagi data produksi yang tampil sehingga perbaikan dinyatakan berhasil dengan tidak terhambatnya pemuatan dan target dapat tercapai.

Langkah yang selanjutnya adalah CHECK, yaitu pengontrolan terhadap hasil dari perbaikan, yang terdiri dari:

1. Perbandingan Terhadap Penyebab Dominan .

Dalam meneliti hasil, GKM Data membandingkan data sebelum perbaikan dengan sesudah perbaikan terhadap hasil namun belum melakukan perbandingan terhadap masing - masing penyebab, terhadap judul dan terhadap tema sehingga penulis mengarahkan kepada tahapan meneliti hasil yang lebih akurat sebagai berikut :

a. Penyebab Program Quantity Manual.

Pada penyebab ini diketahui bahwa sebelum perbaikan terdapat frekuensi salah data sebanyak 23 kali, namun setelah dilakukan perbaikan terdapat 0 kali frekuensi salah data, artinya bahwa perbaikan membuat program quantity otomatis dapat mengatasi frekuensi salah data sehingga tidak ada lagi data yang salah.

b. Penyebab Program tidak bisa switch data kapal.

Sebelum perbaikan dilakukan terdapat 17 kali frekuensi program bag counting rusak, , setelah perbaikan dilakukan dengan membuat Program aplikasi kade kapal maka frekuensi program bag counting rusak menjadi 0 kali. Hal 
ini berarti bahwa membuat program aplikasi kade kapel merupakan perbaikan yang tepat karena dapat menghilangkan penyebab dominan.

c. Penyebab Data Kapal Tidak Tampil. Sebelum perbaikan dilakukan terdapat 18 kali frekuensi data berthing line tidak dapat diproses. Dengan membuat program database kapal maka maka tidak ada lagi frekuensi data berthing line yang tidak dapat diproses, semua data berthing line dapat diproses, .Perbaikan yang dilakukan sudah tepat dalam menghilangkan penyebab.

d. Penyebab Pindah Packer.

Terdapat frekuensi kode packer berubah yang tinggi / sering terjadi dengan tingkat keseringan sebanyak 39 kali sebelum perbaikan dilakukan. Dengan membuat program aplikasi back up kode packer maka tingkat keseringan berubahnya kode packer menjadi 0 kali, dengan demikian perbaikan yang ditentukan sudah tepat dan berhasil mengatasi penyebab.

e. Penyebab Delete D.O.

Pada penyebab ini diketahui bahwa terdapat D.O. hilang sebanyak 21 kali karena terdelete. Perbaikan yang dilakukan adalah dengan membuat program link database D.O. sehingga setelah perbaikan terjadi perubahan signifikan dengan kondisi tidak ada lagi D.O. yang hilang sehingga perbaikan ini berhasil menghilangkan penyebab dominan.

f. Penyebab Shipment lama belum disclosing.

Sering terjadinya shipment list tidak tampil merupakan parameter yang diukur untuk menggambarkan bahwa terjadi penyebab shipement lama belum diclosing yaitu sebanyak 15 kali seperti pada tabel 4.23. Hal ini diperbaikan dengan membuat program closing shipment sehingga diketahui bahwa setelah perbaikan dilakukan shipment list selalu tampil dan proses pemuatan dapat dilakukan seperti pada tabel 4.32. Hal ini menggambarkan bahwa penyebab dominan dapat dihilangkan.

g. Penyebab petugas bag counting belum mengetahui cara mendapatkan gambaran masalah.

Sebelum perbaikan dialakukan yang terjadi adalah petugas MIS lama dalam mengatasi permasalahan yaitu rata rata > 100 menit. Namun setelah dibuatnya program link capture masalah maka petugas MIS lebih cepat dalam mengatasi masalah dengan durasi rata- rata maksimum 5 menit.

h. Penyebab Server Error.

Server error yang acap kali terjadi sebelum perbaikan diindikasikan dengan adanya data produksi yang tidak tampil sebanyak 15 kali. Dengan dibuatnya program reset server maka frekuensi data produksi tidak tampil menjadi 0 kali sehingga dapat disimpulkan bahwa perbaikan dapat menghilangkan penyebab dominan.

2. Perbandingan terhadap Judul.

a. Frekuensi Gangguan Loading System. Sebelum perbaikan dilakukan terdapat gangguan bag counting system pada komputerisasi loading system sebanyak 56 kali dan merupakan gangguan dominan pada komputerisasi loading system. Setelah perbaikan dilakukan terdapat gangguan pada bag counting system sebanyak 0 kali dan tidak lagi menjadi gangguan yang dominan.

b. Durasi Ganguan Loading System.

Sebelum perbaikan dilakukan terdapat gangguan bag counting system pada komputerisasi loading system selama 24 jam dan merupakan gangguan dominan pada komputerisasi loading system. Setelah perbaikan dilakukan terdapat gangguan pada bag counting system sebanyak 0 jam dan tidak lagi menjadi gangguan yang dominan. 
c. Lost Product.

Sebelum perbaikan dilakukan terdapat gangguan bag counting system pada komputerisasi loading system yang mengakibatkan timbulnya lost product sebesar 1.800 ton dan merupakan gangguan dominan pada komputerisasi loading system. Setelah perbaikan dilakukan tidak ada lagi lost product yang diakibatkan tidak ada lagi gangguan pada bag counting system dan tidak lagi menjadi gangguan yang dominan.

d. Nilai Kerugian.

Akibat adanya gangguan pada bag counting system yang merupakan gangguan dominan maka terdapat nilai kerugian sebesar Rp. 1.980.000.000,-. Setelah perbaikan dilakukan dan hilangnya gangguan bag couting system maka tidak ada lagi nilai kerugian yang diakibatkan dari penyebab dominan.

3. Perbandingan Terhadap Tema.

a. Frekuensi Gangguan

Sistem

Komputerisasi.

Sebelum perbaikan dilakukan terdapat loading system pada sistem komputerisasi sebanyak 86 kali dan merupakan gangguan dominan pada sistem komputerisasi. Setelah perbaikan dilakukan terdapat gangguan pada loading system sebanyak 20 kali atau turun sebesar $76,74 \%$ dan tidak lagi menjadi gangguan yang dominan.

b. Durasi Ganguan Sistem Komputerisasi. Sebelum perbaikan dilakukan terdapat gangguan loading system pada sistem komputerisasi selama 38 jam dan merupakan gangguan dominan pada sistem komputerisasi. Setelah perbaikan dilakukan terdapat gangguan pada loading sistem sebanyak 6 jam atau turun sebesar $84,21 \%$ dan tidak lagi menjadi gangguan yang dominan.

\section{c. Lost Product.}

Sebelum perbaikan dilakukan terdapat gangguan loading system pada sistem komputerisasi yang mengakibatkan timbulnya lost product sebesar 2.850 ton dan merupakan gangguan dominan pada sistem komputerisasi,. Setelah perbaikan dilakukan terdapat lost product sebesar 450 ton atau turun sebesar $84,21 \%$ dan masih menjadi dominan.

\section{d. Nilai Kerugian.}

Akibat adanya gangguan pada loading system yang merupakan gangguan dominan maka terdapat nilai kerugian sebesar Rp. 3.135.000.000,-. Setelah perbaikan dilakukan dan turunnya gangguan loading system maka nilai kerugian menjadi turun sebesar Rp. 495.000.000,- atau trurun sebesar $59 \%$ namun masih tetap menjadi yang dominan..

Langkah yang ke empat adalah ACTION, atau disebut juga sebagai tindak Lanjut Hasil Perbaikan, yaitu Membuat Standar Baru. Setelah diketahui bahwa hasil yang dicapai dari penelitian ini adalah tidak adalagi gangguan pada bag counting yang berdampak kepada lost product dan nilai kerugian terhadap pengiriman semen bag via laut menjadi berkurang, maka langkah selanjutanya dalam rangkaian PDCA adalah adalah Action, dimana dalam Action diawali dengan pembuatan standar baru yang terdiri dari :

1. Standar Pembuatan.

Dalam membuat standar prosedur pembuatan harus mengcu kepada langkah - langkah pembuatan yang tercantum pada tahap melaksanakan perbaikan ( $D O$ ). Adapun prosedur yang sudah dibuat adalah sbb :

- Standar Prosedur Pembuatan Program Quantity Otomatis.

- Standar Prosedur Pembuatan Program Aplikasi Kade Kapal Alternatif.

- Standar Prosedur Pembuatan Database Kapal.

- Standar Prosedur Pembuatan Program Aplikasi Back Up Kode Packer.

- Standar Prosedur Pembuatan Program Link Database D.O. 
- Standar Prosedur Pembuatan Program Aplikasi Clossing Shipment.

- Prosedur Pembuatan Program Link Capture Masalah.

- Prosedur Reset Server Eror.

2. Standar Perawatan.

Standar perawatan dibuat dengan maksud agar peralatan yang dibuat sudah terencana program perawatannya. Adapun standar perawatan yang sudah dibuat adalah sbb :

- Standar Prosedur Perawatan Program Quantity Otomatis.

- Standar Prosedur Perawatan Program Aplikasi Kade Kapal Alternatif.

- Standar Prosedur Perawatan Database Kapal.

- Standar Prosedur Perawatan Program Aplikasi Back Up Kode Packer.

- Standar Prosedur Perawatan Program Link Database D.O.

- Standar Prosedur Perawatan Program Aplikasi Clossing Shipment.

- Prosedur Perawatan Program Link Capture Masalah.

- Prosedur perawatan Server .

3. Standar Pengoprasian.

Agar setiap petugas yang berwenang dapat mengoprasikan peralatan / program yang sudah dibuat, maka dibuat juga standar prosedur pengoprasian. Adapun standar pengoprasian yang sudah dibuat adalah sbb :

- Standar Prosedur Pengoprasian Program Quantity Otomatis.

- Standar Prosedur Pengoprasian Program Aplikasi Kade Kapal Alternatif.

- Standar Prosedur Pengoprasian Database Kapal.

- Standar Prosedur Pengoprasian Program Aplikasi Back Up Kode Packer.

- Standar Prosedur Pengoprasian Program Link Database D.O.

- Standar Prosedur Pengoprasian Program Aplikasi Clossing Shipment.

- Prosedur Pengoprasian Program Link Capture Masalah.
- Prosedur pengoprasian Server.

4. Standar Hasil.

Standar hasil adalah standar yang dibuat berdasarkan hasil yang telah dicapai. Dengan melaksanakan semua prosedur yang sudah dibuat secara konsisten maka standar hasil yang dibuat dapat tercapai sehingga permasalah yang sama tidak terulang. Adapun standar hasil yang telah dibuat adalah gangguan bag counting system maksimum 0 jam dalam sebulan.

\section{Kesimpulan}

Pelaksanaan deming's cycle yang tepat dapat membantu perusahaan untuk melakukan pendeteksian atas segala permasalahan yang ada di perusahaan dan secepatnya bisa melakukan tindakan koreksi. Penerapan deming's cycle di PT Indocement Tunggal Prakarsa Tbk membantu perusahaan mendeteksi faktor-faktor penyebab terjadinya defect dan mencari solusi untuk mengurangi jumlah produk cacat melalui pembentukan GKM.

Penelitian ini diharapkan membawa manfaat bagi berbagai pihak, misalnya bagi perusahaan penelitian ini diharapkan dap mengurangi gangguan pada proses distribusi semen bag via laut karena potensi lost product dan nilai kerugian berkurang, target distribusi dapat ditingkatkan, meningkatkan pengetahuan karyawan, serta meningkatkan motivasi kerja karyawan. Bagi Pengembangan Ilmu Pengetahuan, penelitian ini diharapkan dapat lebih memperkaya pengetahuan tentang Implementasi Deming Cycle dalam mengatasi permasalahan kualitas pada operasional proses bisnis yang lebih analisis dengan metodologi Tujuh Langkah Tujuh Alat Bantu dan dapat dijadikan referensi perpustakaan dan dapat dijadikan perbandingan bagi penelitian berikutnya.

Saran yang didapatkan dari hasil penelitian ini meliputi:

1. Penggunaan alat bantu statistic yang update seperti The New 7 Tools dapat digunakan agar hasil analisa lebih akurat dan dapat menentukan pengambilan keputusan yang lebih tepat. 
2. Perlu juga pengukuran terhadap tingkat budaya improvement pada satu - satunya karyawan dengan metode Total Quality Personal ( $T Q P$ ) dalam perusahaan.

3. Lakukan analisa juga terhadap peran fasilitator sehingga dapat diukur juga dengan Radar Chart .

\section{DAFTAR PUSTAKA}

Gaspersz, Vincent, 2005, Total Quality Management, PT Gramedia Pustaka Utama, Jakarta.

Yamit, Zulian, 2010, Manajemen Kualitas Produk \& Jasa, Ekonisia, Jogjakarta.

Chang, Richard Y \& P. Keith Kelly, 2003, Langkah - Langkah Pemecahan Masalah , PT Pustaka Binaman Pressindo, Jakarta.

Sujarweni, V. Wiratna, 2015, Metodelogi Penelitian Bisnis \& ekonomi, Pustakabarupres, Jogjakarta.
Bungin, Burhan, 2005, Metodologi Penelitian Kuantitatif, Prenada Media , Jakarta.

Sugian, Syahu, 2006, Kamus Manajemen Mutu ,PT. Gramedia Pustaka Utama Jakarta.

Sunyoto, Danang, 2014, Dasar - dasar Manajemen Pemasaran , Bukuseru, Jakarta.

Karatsu, Hajime \& Toyoki Ikeda, 1985, Mastering The Tools Of Q.C. PHP Institute Inc, Tokyo .

Nayatani, Yoshinobu, Toru eiga, Ryoji Futami, Hiroyuki Miyagawa, 1994, The Seven New QC Tools - Practical Applications for Managers 3A Corporation, Tokyo.

Wiyanti, Ignatia Rini, 2016, PDCA TULTA - Metode Praktis Untuk Pemecahan Masalah dan Peningkatan Mutu Di Semua Sektor Usaha dan Bidang Kerja. 